\title{
DEVELOPING APPLICATIONS FOR MAC OS X AND iOS
}

\section{Jan LAVRINČÍK}

\section{VÝVOJ APLIKCÍ PRO MAC OS X A IOS}

KOCHAN, S. G. Objective-C 2.0: Výukový kurz programováni pro Mac OS X a iPhone. 1. vyd. Brno : Computer Press, 2010. 550 s. ISBN 978-80-251-2654-7.

Je vždy velmi př́ijemné dostat do ruky a recenzovat knihu, která je něčím výjimečná a od těch ostatních se liší obsahem. Knihu s názvem Objective-C 2.0: Výukový kurz programování pro Mac Os $\mathrm{X}$ a iOS napsal Stephen Kochan. Jako zajímavost můžeme zmínit, že v současné době v anglickém originále vyšlo již tretí vydání recenzované knihy. Autor se věnuje programování pro platformu Mac už od představení prvního Macintoshe v roce 1984. Je autorem nebo spoluautorem řady knih zaměřených na programování $\mathrm{v}$ jazyce $\mathrm{C}$. $\mathrm{Z}$ těch nejznámějších titulů vybíráme

Programming in C (Sams, 2004), Programming in ANSI C (Sams, 1994), Topics in C Programming (Wiley, 1991). Operačním systémům Unix věnuje pozornost $\mathrm{v}$ dílech Exploring the Unix System (Sams, 1992), Unix Shell Programming (Sams 2003). V neposlední řadě uvádíme knihy pro Mac; Programming in Objective-C (Sams, 2003), Beginning AppleScript (Wiley, 2004).

Pro dobrou orientaci v knize je velmi důležité zvolit optimální tř́iění. To autor recenzované publikace vyřešil rozdělením knihy do čtyr hlavních částí, které dále dělí na tematicky zaměřené kapitoly. Na začátku pro snazší práci s knihou nacházíme dokonce dva obsahy, jeden stručný, kde najdeme rozdělení na části a názvy jednotlivých kapitol a podrobný, kde je strukturovaný obsah i včetně podkapitol.

První lekce je velmi důležitá, popisuje specifika programování v operačním systému Mac OS X. Programovací nástroj Xcode, jenž je součástí instalačního DVD (XcodeTools.mpkg) s operačním systémem (např. plnohodnotné vývojové nástroje pro Windows je nutno zakoupit samostatně). $\mathrm{Na}$ obrázcích autor zobrazuje př́stup k tvorbě iOS aplikací (iPhone, iPod, iPad) a klasické desktopové pro Mac OS X. Zmínka je zde i o prííponách zdrojových kódů. Ve většině př́padů mají pouze jeden znak (např. .c, .h, .m. .o). V druhé lekci nám autor zlehka odhaluje tajemství trríd, objektů a metod programování v nástroji XCode. Problematiku

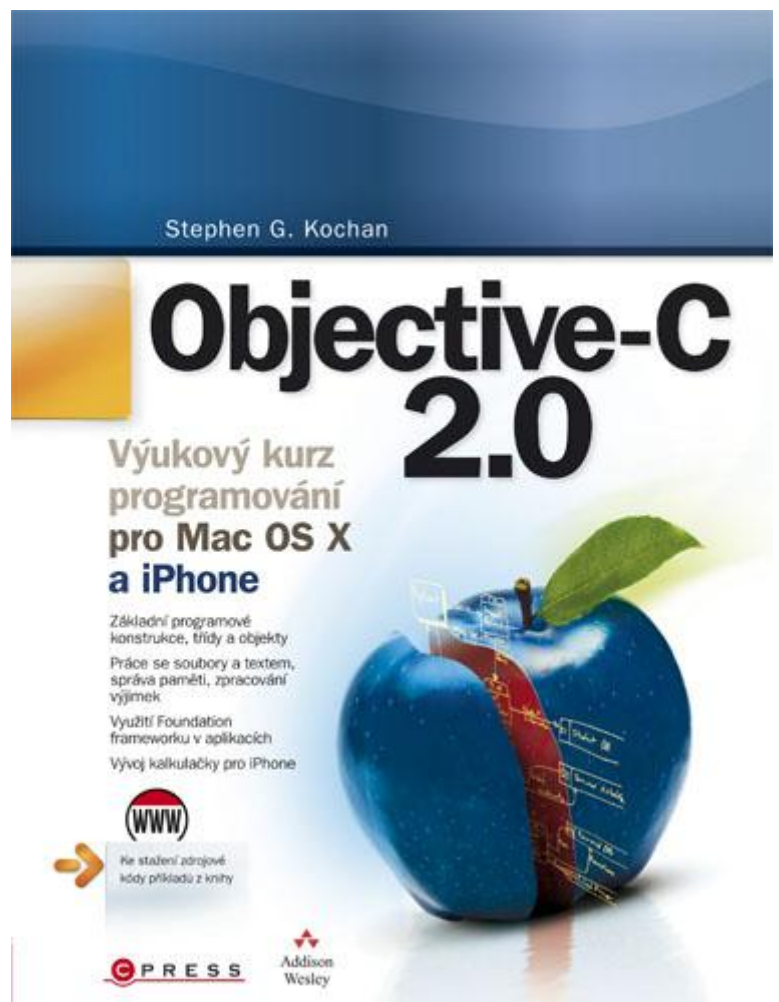

objekti̊ autor demonstruje na objektu auto a vlastnostech barvy, barvy interiéru, typu karosérie apod. U instancí a metod nás seznamuje se syntaxí zdrojových kódů. V textu je rozeznáme dle charakteristického písma podobného písmu Courier New. Závěr lekce je obohacen o souhrn základních poznatků a sedm cvičení. Třetí lekce je nepostradatelnou při budování teoretického aparátu poznatků v programování v Objective-C 2.0. Datové typy a konstanty představují základ práce u každé vyvíjené aplikace. Dozvídáme se zde, že k práci můžeme využít základního datového typu int (pro práci s celými čísly), float (pro čísla i s desetinnou čárkou), double (float s využitím rozsahu až 64 bitů) a char (slouží k uložení pouze jednoho znaku - znaková konstanta). Čtvrtá lekce věnuje svou pozornost cyklům a smyčkám. Mimo typických struktur typu for a while, zde najdeme něco i o prŕkazech break a continue. Pro pátou lekci zvolil autor obsahovou náplň 
s názvem rozhodování. Zde patří typické podmínky if, ale i méně typické př́kazy switch a podmínkové operátory (ternární operátory).

Od šesté lekce už se začínáme setkávat s poměrně náročnými tématy, kterými jsou bezesporu třídy, dědičnost, dynamické typování nebo fragmenty o proměnných a datových typech.

Za zmínku stojí ještě poslední (dvanáctá lekce) první části. Zde jsou blížeji popsány zajímavé prvky jazyka C - pole, funkce a struktury.

Druhá část knihy nás učí, jak nakládat s kolekcí trríd, metod, funkcí, podpưrných zdrojů a dokumentací logicky, tak abychom jednodušeji sestavili požadovanou aplikaci. V systému Mac OS X jich máme $\mathrm{k}$ dispozici více než 80 pro práci se strukturou složek Mac, vypalování $\mathrm{CD}$, přehrávání multimédií apod. Autor zde poprvé zavádí nový termín Cocoa pro frameworky Foundation a Application Kit. Více se s ním budeme setkávat až v poslední části knihy. $\mathrm{V}$ šesti kapitolách druhé části př́ručky s využitím frameworků budeme efektivněji pracovat $\mathrm{s}$ čísly, řetězci, kontejnery či archivovat data $\mathrm{v}$ operačních systémech Mac OS X nebo si vyzkoušíme práci se soubory, správou paměti počítače, kopírovat objekty.

Předposlední část knihy $\mathrm{s}$ číslem tři je věnována vývoji aplikací pro mobilní platformu iOS za pomocí Cocoa. V úvodu kapitoly se autor snaží o vysvětlení rozdílu v dosavadním př́stupu ve vývoji pro Mac OS X a iOS. Studium zhruba třiceti stran činí poutavější a zajímavější i čekání na funkční aplikaci $\mathrm{v}$ podobě kalkulačky pro mobilní telefony iPhone kompletně zdokumentovanou $\mathrm{v}$ předposlední části knihy. Poslední část už tvoří jen př́lohy v podobě glosáře, zdrojových kódů a rejstř́íku.

Už pomalu typickým rozpoznávacím znakem nakladatelství Computer Press jsou knihy v měkkém přebalu, které trpí vysokou mírou mechanického opotřebení. U knihy určené pro luxusní produkty značky Apple by se hodil stejně kvalitní přebal, který má kniha Mac OS X Snow Leopard: kompletní průvodce a jednotlivé listy na křídovém papíře. Malou útěchou pro všechny „nadšence“ platformy Macintosh může být graficky povedený přebal. Standardní cena knihy je stanovena na 790 Kč, což je sice vyšší průměr, ale na knihy s tematikou ICT běžný standard.

Kniha je kvalitní a neobsahuje téměř žádné obsahové chyby, spíše místy narážíme na vyšší obtížnost textu. V knize jen stěží hledáme pseudoformální nedostatky (překlepy), které mohly vzniknout při překladu a přepisu textu. Jedna z mála se nachází např. na straně 22 „XocdeTools.mpkg“. Můžeme podotknout, že redaktoři Tomáš Kolář a Alena Láníčková odvedli výbornou práci.

Ze zajímavostí můžeme zmínit diskusní fórum na adrese http://classroomm.com/objective-c, které je problematice této knihy věnováno. Nacházíme zde některé př́klady dále rozpracovány, upozornění na logické chyby, tipy a triky s vývojovým nástrojem XCode apod.

Kniha je přeložena $\mathrm{z}$ anglického originálu s názvem Programming in objektive-C 2.0 Karlem Voráčkem. Překlad je velmi zdařilý, text je přehledný s logickou větnou výstavbou. I v částech s popisem zdrojových kódů si text zachoval odbornost a přesnost.

Závěrem bychom mohli říct, že se jedná o velmi zdařilou knihu, která vyplňuje „mezeru“ na českém knižním trhu. Učí př́stup $\mathrm{k}$ vývoji aplikací pro operační systém Mac Os X a mobilní operační systém iOS. V současné době se tato zařízení v celosvětovém žebříčku i přes vysoké ceny velmi dobře prodávají a díky své filozofii jsou mimo jiné velmi vhodné pro výuku na různých vzdělávacích stupních at' už se jedná o platformu MacBook, iMac nebo iPad.

Kniha se pustila do obtížné oblasti, protože knih podobného zaměření zejména $\mathrm{v}$ českém jazyce př́liš není. Př́istup, který autor zvolil je velmi dobrý a poskytuje kvalitní teoretický aparát doplněný o vhodně zvolené zdrojové kódy. Pro člověka, který se teprve chystá začít s programováním je kniha velmi obtížná. Kniha je vhodná pro programátora nebo člověka se znalostmi algoritmizace $\mathrm{z}$ jiných programovacích jazyků. Určitě u těchto lidí najde své pevné místo v knihovně. Pro začátečníky a zájemce doporučujeme začít $\mathrm{s}$ jednoduššími knihami o programování pro jazyk Visual Basic nebo $\mathrm{C}++$ pod operačním systémem Windows, pochopit logiku algoritmizace a pod operační systém Apple Mac OS X přjít později.
PhDr. Jan Lavrinčík, DiS.
Katedra technické a informační výchovy
Pedagogická fakulta UP
Žižkovo nám. 5, 771 40, Olomouc,
\& Ústav informatiky, MVŠO
Jeremenkova 1142/42
Tel.: +420 585635813
E-mail: nobilis.felis@ seznam.cz
Wwwpracovišstě:www.kteiv.upol.cz 